\title{
PENANAMAN POHON SEBAGAI UPAYA MENJAGA CADANGAN AIR TANAH DAN MENCEGAH BAHAYA EROSI DI KECAMATAN CIBIRU
}

\author{
Kundang Harisman $^{1)}$, Budy Frasetya ${ }^{2}$, Adjat Sudrajat ${ }^{3)}$, Suryaman Birnadi ${ }^{4}$, Maratun \\ Sholeha ${ }^{5)}$ \\ Jurusan Agroteknologi, Fakultas Sains dan Teknologi, UIN Sunan Gunung Djati Bandung \\ ${ }^{1)}$ kundangharisman@yahoo.com ${ }^{2)}$ budyfrasetya@ uinsgd.ac.id ${ }^{3)}$ adjatsudrajat59@ gmail.com ${ }^{4)}$ \\ sbirnadi_6165@yahoo.com ${ }^{5)}$ rmaratun@gmail.com
}

\begin{abstract}
Abstrak
Perubahan penggunaan lahan menjadi pemukiman dan lahan pertanian menyebabkan air hujan yang turun tidak dapat langsung meresap ke dalam tanah. Wilayah di Kecamatan Cibiru termasuk wilayah berlereng sehingga potensi erosi di wilayah ini termasuk tinggi. Tindakan konservasi tanah dan air melalui gerakan menanam pohon dengan melibatkan masyarakat merupakan upaya strategis dalam menurunkan bahaya erosi dan mengalirkan air hujan ke dalam tanah melalui proses infiltrasi. Kegiatan ini dilaksanakan dari bulan Juli-Agustus 2018 dipusatkan di Kelurahan Palasari yang memiliki kemiringan lereng $8-15 \%$. Metode pengabdian yang digunakan dalam bentuk pelatihan penanaman pohon dan pendampingan selama masa penanaman dan pemeliharaan. Kegiatan penaman pohon ini disambut antusias oleh masyarakat. Masyarakat pro aktif dalam memelihara pohon terutama pada musim kemarau.
\end{abstract}

Kata kunci: aliran permukaan, infiltrasi, konservasi vegetatif, potensi erosi

\begin{abstract}
Land use conversion in to settlements and agricultural land affect rainwater can not be infiltrate directly in to the soil. Cibiru District has large area with slope so that this region has high risk of erosion. Soil and water conservation activity through tree planting methode involving comunity services is startegic effort to overcome potential erosion hazzard and increase soil infiltration. The activity of Community services was held from July-August 2018 in Palasari sub-district which has slope 8-15\%. This community services methode used in the form of tree planting workshop and supervision during the manintenance periode. This tree planting program was welcomed enthusiastically by the community. The comunity in Cibiru District is pro active in preservation trees, especially during the dry season.
\end{abstract}

Keywords: run off, infiltration, vegetative conservation, community services

\section{PENDAHULUAN}

Berdasarkan data Badan Pusat Statistik Kota Bandung (2017) Kecamatan Cibiru terdiri dari empat kelurahan yang memiliki luasan daerah sebagai berikut : Kelurahan Cisurupan memiliki wilayah terluas $(232,43$ ha) diikuti oleh Kelurahan Palasari $(175,09)$, Kelurahan Pasir Biru (158,72 ha), dan Kelurahan Cipadung $(117,97)$. Hutan sekunder yang ada di wilayah kecamatan Cibiru hanya sekitar 6,7 \% dari luasan kecamatan cibiru sedangkan untuk permukiman berkisar $25 \%$ dari luasan kecamatan Cibiru. Persentase permukiman yang lebih besar dapat menyebabkan daya serap air berkurang.

Berkurangnya daya serap air di kawasan Kecamatan Cibiru menyebabkan tingkat erosi dan banjir cukup tinggi pada daerah rendah dibawah kecamatan Cibiru. Sehingga persentase bencana alam longsor atau banjir semakin meningkat. Oleh karena itu perlu dilakukan rehabilitasi didaerah dataran tinggi (Frasetya, 2015). Kecamatan Cibiru dengan cara Penanaman pohon di daerah kritis diharapkan dengan adanya penghijauan pada kawasan kritis Kecamatan Cibiru dapat mengurangi bencana longsor dan banjir serta berfungsi sebagai daerah penyangga. 
Aliran permukaan yang tinggi akibat kerapatan vegetasi rendah meyebabkan kompaksi tanah sehingga proses infiltrasi air hujan ke dalam profil tanah sangat rendah. Dampaknya cadangan air tanah menurun terutama sangat dirasakan pada saat musim kemarau. Permasalah yang umum terjadi di musim kemarau di wilayah Kecamatan Cibiru adalah ketersediaan air bersih terutama di daerah-daerah yang berdekatan dengan Kawasan Bandung Utara (KBU) seperti Kelurahan Cisurupan. Kondisi ini sangat ironis seharusnya daerah-daerah atas masayarakatnya tidak mengalami keterbatasan air bersih di musim kamarau. Upaya penanaman pohon diharapkan dapat mengatasi keterbatasan air tanah pada 5-10 tahun kedepan.

Partisipasi masyarakat untuk menjaga kelestarian lingkungan di wilayah Kecamatan Cibiru perlu ditingkan dengan memberikan informasi tentang pentingnya menanam pohon sebagai salah satu kegiatan konservasi dan pelatihan pemeliharan tanaman yang telah ditanam oleh masyrakat secara swadaya maupun yang ditanam oleh pemerintah untuk dijaga secara bersama.

Komunitas yang dijadikan sasaran pada kegiatan penanaman pohon adalah seluruh masyarakat di Kecamatan Cibiru, namun sebagai percontohan agar pelatihan tepat sasaran dan kemudahan monitoring dipilihlah pasukan Go-Ber yang merupakan tim kebersihan yang berada di setiap kelurahan. Tim Go-Ber direkrut dari masyarakat di sekitar kelurahankelurahan yang ada di Kecamatan Cibiru.

Tim Go-Ber merupakan target sasaran strategis dikarenakan selain mereka memelihara kebersihan di lingkungan kelurahan masingmasing, keberadaan mereka dapat diberdayakan sebagai garda depan dalam penanaman pohon. Peningkatan keahlian pemeliharaan pohon tim Go-Ber ini selain efektif, mereka selalu siap siaga di lingkungan sehingga diharapkan pemeliharaan tanaman dapat berjalan maksimal.

Pelaksanaan kegiatan penanaman pohon ini diaharapkan dapat memotivasi masyarakat di wilayah Kecamatan Cibiru untuk berperan aktif dalam mengurangi dampak kerusakan lingkungan, diantaranya:
1. Daerah rawan longsor di daerah Kecamatan Cibiru menjadi hijau kembali dengan adanya penanaman pohon.

2. Cadangan air tanah di dataran tinggi wilayah kecamatan Cibiru meningkat

3. Mengurangi terjadinya longsor dan banjir di daerah dataran rendah Kota Bandung khususnya wilayah Bandung Timur.

\section{METODOLOGI PENGABDIAN}

Strategi yang digunakan dalam pelaksanaan pengabdian ini dibagi kedalam dua tahap yaitu:

1. Pelatihan metode konservasi tanah dan air

2. Penanaman dan pemeliharaan pohon

3. Pendampingan pada awal tanam pohon

Pelaksanaan pengabdian penanaman pohon ini mengacu pada model desain instruksional Analysis-Desain-DevelopImplement-Evaluate (ADDIE). Model ini dikembangkan oleh Reiser dan Mollenda (1990an) yang merupakan model desain pembelajaran/pelatihan yang berifat generic serta menjadi pedoman dalam membangun perangkat dan infrastuktur program pelatihan yang efektif, dinamis dan mendukung kinerja pelatihan itu sendiri.

Tahapan pada model ADDIE ini menggunakan 5 tahap atau langkah pengembangan (Gambar 1).

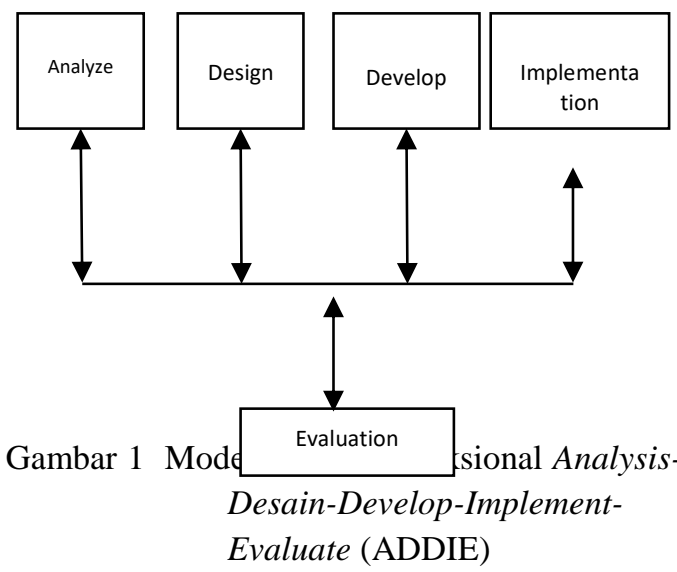

\section{Analisis (Analyze)}

Tahap analisis merupakan suatu proses needs assessment (analisis kebutuhan), mengindentifikasi masalah (kebutuhan) dan melakukan analisis tugas (task analyze). Hasil yang dihasilkan berupa pemilihan titik daerah 
yang membutuhkan penghijauan. Penentuan titik menguunakan Sistem Informasi Geografis (SIG). Kegiatan yang dilakukan ialah mengadakan Focus Group Discussion (FGD) dengan melibatkan pengurus kecamatan dan kelurahan di kecamatan Cibiru, dari hasil diskusi dapat titik daerah yang operlu dilakukan penanaman pohon.

\section{Design (Design)}

Kegiatan pada tahap ini merancang desain penanaman pada lahan terbatas. Tim pelaksana melakukan observasi wilayah yang terbuka tanpa vegetasi tanaman pelindung dan berpotensi terjadi erosi dan longsor (Gambar 2) untuk merancang model penanaman, dari hasil observasi didapat model penaman pohon lahan berlereng dan daerah yang gundul.

\section{Pengembangan (Development)}

Kegiatan pada tahap ini membangun strategi penanaman dan pemeliharaan pohon yang sudah ditanam agar tetap tumbuh dan terjaga, sehingga pohon tersebut dapat meningkatkan cadagan air dan mengurangi tingkat erosi di wilayah Kecamatan Cibiru.

\section{Implementasi (Implementation)}

Kegiatan pada tahap ini menerapkan penananman dan pembinaan pada titik-titik daerah yang sudah ditentukan. Sebelum menerapkan, tim pengabdian dan warga melakukan pelatihan dan pembinaanketerkaitan fungsi, pemeliharaan pohon yang sudah ditanam

\section{Evaluasi (Evaluation)}

Evaluasi dilakukan oleh tim terkait pada wilayah-wilayah yang sudah menjadi titik penanaman pohon. Evaluasi awal tentang penyampaian materi dan praktek penanaman pohon serta memberikan questioner keterkaitan dengan penghijauan pada saat FGD. Demikian pula akan diberikan questioner di akhir kegiatan keterkaitan dampak yang dihasilkan setelah adanya kegiatan pengabdian ini. Selain itu evaluasi dilakukan setelah tim pengabdian melakukan pendampingan pada warga disekitar titik lokasi penanaman pohon.

\section{PELAKSANAAN KEGIATAN}

Kegiatan pelatihan dan pemeliharaan pohon di pusatkan di Kelurahan Palasari dan Kelurahan Cisurupan kegiatan ini sangat penting dilakukan dikarenakan sebagaian masyarakat masih beranggapan bahwa tanaman kayu atau pohon pelindung tidak perlu dirawat. Sama halnya dengan tanaman lain, tanaman kayu 1-3 tahun dari pindah tanam memerlukan perawatan terutama di musim kemarau.

Kegiatan ini mencakup pemilihan lokasi, metode pemupukan dan strategi pemeliharaan tanaman di musim kemarau untuk meminimalisir penyiraman dengan tetap memperhatikan pertumbuhan tanaman. Kegiatan pelatihan dilaksanakan di ruang serba guna Kelurahan Palasari. Kegiatan pelatihan ini tidak hanya melibatkan Dosen Jurusan Agroteknologi UIN SGD Bandung namun mahasiswa diikutsertakan pada kegiatan ini. Mahasiswa berperan untuk melakukan monitoring kondisi tanaman yang telah ditanam. Pada kegiatan ini diberikan stimulus berupa bibit tanaman keras (Gambar 2) yang bermanfaat hasil kayunya seperti Pohon Albasia.

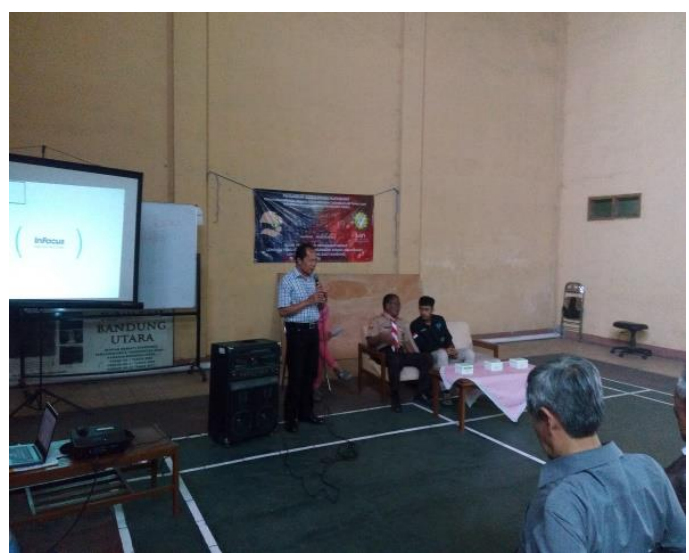

Gambar 2 Kegiatan Pelatihan oleh Ketua Tim Ir. Kundang Harisman, M.Si.

Kegiatan pelatihan ini diikuti oleh kurang lebih 60 orang (Gambar 4). Antusiasme masyarakat terlihat dari sesi tanya jawab terkait pemeliharaan, munculnya konflik kepentingan antara petani dengan program penanaman pohon terjadi dikarenakan petani beranggapan bahwa pohon-pohon yang ditanam akan menghalangi sinar matahari dan menggangu produktivitas tanaman yang dibudidayakan. Kondisi ini memerlukan pendampingan untuk memberikan pengertian kepada petani bahwa pohon-pohon 
yang ditanam dapat membantu petani menekan kerusakan tanah akibat erosi.

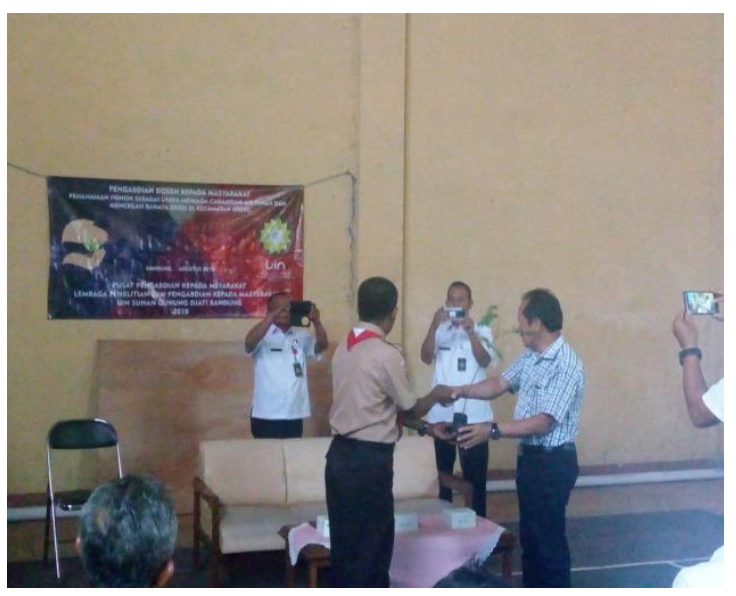

Gambar 3 Serah Terima Secara Simbolis Pohon Pelindung

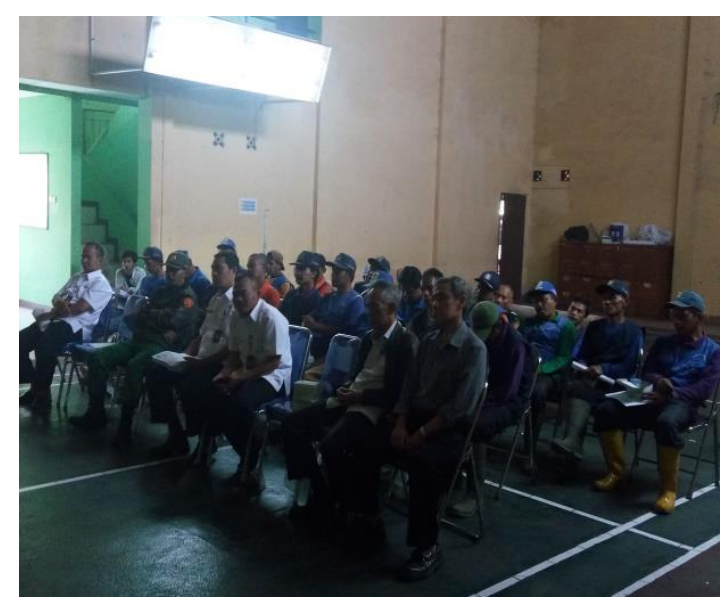

Gambar 4 Peserta Menyimak Pemaparan Materi dari Ketua Tim Pengabdi

\section{HASIL DAN PEMBAHASAN}

\section{A. Peran Masyarakat dalam Konservasi Tanah dan Air}

Perubahan penggunaan lahan sebagai bentuk pemanfaatan sumberdaya lahan seiring dengan bertambahnya jumlah penduduk dan kemajuan teknologi di berbagai sektor mendorong lahan-lahan pemanfaatan lahan tidak sesuai dengan kesesuaian lahannya. Pemanfaatan lahan yang tidak sesuai dengan kesesuaian lahannya menyebabkan degradasi lahan (Arsyad, 2006). Sebagai sumber daya alam untuk pertanian tanah memiliki dua fungsi sebagai tempat tegaknya tanaman dan sebagai sumber nutrisi bagi tanaman. Menurunnya fungsi ekologi tanah tidak hanya dipengaruhi oleh penggunaan lahan untuk infrastruktur seperti pemukiman, pembangunan fasilitas umum dan fasilitas sosial, aktivitas pertanian merupakan salah satu penyumbang rusaknya ekologi tanah.

Aktivitas penggunaan lahan yang tidak memperhatikan konservasi tanah dan air telah menyebabkan terjadinya kerusakan lingkungan salah satunya ketidak seimbangan antara hujan dan kemampuan tanah untuk menginfiltrasi hujan yang turun masuk ke dalam matriks tanah. Akibatnya air hujan yang turun akan mengalir di permukaan kemudian secara cepat akan mengisi saluran drainase dan apabila saluran drainase tidak mampu menamung aliran permukaan maka mulailah terbentuk genangan di permukaaan yang sifatnya sementara maupun permanen.

Hilangnya vegetasi di Kecamatan Cibiru tidak dapat dihindari karena adanya aktivitas pembangunan pemukiman dan aktivitas budidaya pertanian pada lahan-lahan yang dimiliki warga maupun lahan-lahan yang dimiliki pemerintah Kota Bandung. Hasil survei penentuan lokasi pengabdian menunjukkan bahwa beberapa titik lahan pertanian pada lahan berlereng dibiarkan terbuka padahal hal tersebut dapat menyebabkan erosi. Penanaman tanaman pelindung di areal lahan pertanian masih dianggap sebagai pengganggu sinar matahari masuk ke lahan pertanian.

Kegiatan pengabdian yang dilakukan tidak hanya memberikan informasi kepada masyarakat tetapi memberikan contoh bentuk konservasi yang sinergi dengan aktivitas pertanian sehingga konflik kepentingan dengan petani dapat diatasi secara produktif. Hilangnya secara berlebihan lapisan tanah atas karena erosi dapat menyebabkan kesuburan tanah menurun dan biaya produksi pengolahan tanah dan pemupukan meningkat. Program pengabidan ini dapat diterima masyarakat menurut Darmansah et al. (2016) program ini dapat berkelanjutan apabila menjungjung tinggi nilai partisipasi. 
Pada saat pelaksanaan program masyarakat sangat antusias untuk melakukan program penanaman pohon dengan penuh kesungguhan dan tanggung jawab (Gambar 8).

Kegiatan penanaman yang dilakukan masyarakat perlu diberikan pendampingan hal ini dikarenakan tidak semua masyarakat memiliki keterampilan untuk menanam pohon terutama apabila tanaman yang ditanam mengalami kendala seperti kekurangan unsur hara, terkena serangan hama dan penyakit. Kegiatan pendampingan tidak hanya memberikan masukan teori juga menampung kreativitas masyarakat yang secara tidak langsung dapat digunakan sebagai bahan untuk kajian pengembangan untuk mengatasi masalah yang umum dihadapi oleh masyrakat.

Kegiatan penanaman merupakan salah satu tindakan konservasi yang termasuk ke dalam konservasi secara vegetatif. Menurut (Arsyad, 2006) metode konservasi vegetatif merupakan penggunaan tanaman dan tumbuhan atau bagian tumbuhan atau sisa-sisanya untuk mengurangi daya tumbuk butir hujan yang jatuh, mengurangi jumah dan kecepatan aliran permukaan yang pada akhirnya mengurangi erosi. Metode vegetatif dalam konservasi tanah meliputi: penanaman dalam strip, penggunaan sisa-sisa tanaman, geotekstil, strip penyangga, tanaman penutup tanah, pergiliran tanaman, agroforestry.

\section{B. Kendala Penerapan Konservasi}

Penerapan pemanfaatan lahan dengan menerapkan berbagai metode konservasi dihadapkan pada berbagai kendala diantaranya keterbatasan waktu akibat kesibukan msayarakat kota, ketersediaan halaman, lahan berlereng, ketersediaan air untuk irigasi. Kendala penerapan metode konservasi vegetatif ini dengan penanaman pohon adalah apabila menghadapi musim kemarau peran serta masyarakat untuk menyiram tanaman menjadi kendala. Permasalahannya tidak hanya partispasi masyarakat yang masih rendah untuk memelihara tanaman namun ketersediaan air untuk peniraman juga pada saat musim kaemarau terbatas. Pembuatan embung-embung atau kolam retensi juga bukan tanpa kendala, masyrakat umumnya tidak mau lahannya terpakai untuk menampung air hujan, sehingga solusinya pemanfaatan lahan pemerintah untuk dibangun sebagai kolam retensi.

Pembangunan kolam retensi juga perlu perhatian dikarenakan dekat pemukiman faktor keselamatan pembangunan kolam retensi khususnya anak-anak perlu dipertimbangkan sehingga solusi yang dibangun tidak menimbilkan masalah dikemudian hari.

\section{UCAPAN TERIMA KASIH}

Kami ucapkan terima kasih kepada Rektor UIN Sunan Gunung Djati, Ketua LP2M, Ketua Pusat Pengabdian Kepada Masyarakat yang telah membiayai kegiatan ini melalui skema bantuan Pengabdian Kepada Masyarakat Tahun 2018.

\section{PENUTUP}

\section{Kesimpulan}

Kegiatan penanaman pohon sebagai upaya menjaga cadangan air tanah dan menurunkan erosi tanah mendapat respons positif dengan melibatkan masyarakat dan aparatur pemerintahan. Stimulus berupa bantuan bibit diaharapkan dapat diikuti dengan adanya kegiatan swadaya penyediaan bibit tanaman secara mandiri.

\section{Saran}

Penanaman berbagai jenis pohon diharapkan menjadi program masyrakat di tingkat RW sehingga masing-masing wilayah dapat merumuskan kebutuhan bibit sehingga muncul peluang usaha baru untuk menyediakan bibit yang dikelola oleh masyrakat secara mandiri.

\section{DAFTAR PUSTAKA}

Arsyad, S. (2006). Konsevasi Tanah dan Air (2nd ed.). Bogor: IPB Press.

Badan Pusat Statistik Kota Bandung. (2017).

Kecamatan Cibiru dalam Angka 2017.

Bandung: Badan Pusat Statistik Kota Bandung.

Dariah, A., Nurida, N. L., \& Sutono. (2013). Peranan Pembenah Tanah untuk Perbaikan Kualitas Tanah, Peningkatan 
Produksi Tanaman Pangan dan Efisiensi Penggunaan Pupuk pada Lahan Kering di Panjalu, Ciamis, Jawa Barat. In D. K. S. Swastika, K. Suradisastra, \& B. Hutabarat (Eds.), Pemanfaatan dan Pendayagunaan Lahan Terlantar Menuju Implementasi Reforma Agraria (pp. 104-114). Bogor: Pusat Sosial Ekonomi dan Kebijakan Pertanian Kementerian Pertanian.

Darmansah, A., Nugroho, T., \& Supriyono, E. (2016). Pemberdayaan Masyarakat melalui Pengembangan Polikultur Bandeng dan Udang di Desa Karangsong, Indramayu , Jawa Barat ( Community development through Milk Fish and Prawn Polyculture in Karangsong. Agrokreatif, 2(November), 92-99.

Frasetya, B. (2015). Kajian Evaluasi Kerusakan Tanah Pada Lahan Kering dengan Bergbagai Penggunaan Lahan untuk Produksi Biomassa di Kabupaten Subang. Universitas Padjadjaran.

Frasetya, B., Setiati, Y., Septianugraha, R., \& Muhammad, G. (2018). Pemanfaatan Citra Landsat 8 dan Google Earth untuk Identifikasi Lahan Sawah di Kecamatan Cibiru Kota Bandung. E-Jurnal Agroekoteknologi Tropika, 7(3), 428-436.

Frasetya, B., Suriadikusumah, A., \& Harryanto, R. (2016). Evaluasi Kriteria Kerusakan Tanah untuk Produksi Biomassa pada Lahan Kering di Kabupaten Subang. Soilrens, 14(1), 1-5. Retrieved from http://jurnal.unpad.ac.id/soilrens/article/vi ew/9266 